\title{
HEPATOPROTECTIVE EFFECT OF POLYPHENOLS IN RATS WITH EXPERIMENTAL THIOACETAMIDE-INDUCED TOXIC LIVER PATHOLOGY
}

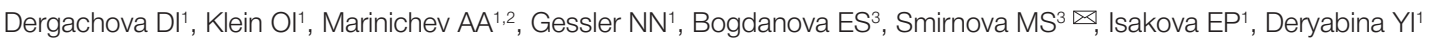

${ }^{1}$ Bach Institute of Biochemistry, Federal Research Centre "Fundamentals of Biotechnology" RAS, Moscow, Russia

${ }^{2}$ Dmitry Mendeleev University of Chemical Technology, Moscow, Russia

${ }^{3}$ Vavilov Institute of General Genetics, Moscow, Russia

Non-alcoholic fatty liver disease is associated with a number of disorders (diabetes, obesity, cardiovascular diseases), and can also be induced by drugs or toxic compounds. Recently the important branch of medicine is the search for effective means of prevention and treatment of fatty hepatosis. Our work was aimed to study the effect of some biologically active natural polyphenols (resveratrol and pinosylvin stilbenes as well as dihydromyricetin dihydroflavonol) on the function and histologic features of the liver. In the experimental model of thioacetamide-induced toxic hepaptitis, the male rats of the Wistar line daily received the effective doses of polyphenols intragastically by gavage together with $0.05 \%$ thioacetamide added to drinking water. All studied polyphenols contributed to stabilization of rat weight and a two-fold significant $(p<0.05)$ decrease in the level of direct bilirubin in the blood serum of animals treated with thioacetamide. Histological analysis of the liver confirmed a decrease in inflammation and hemorrhage in animals treated with polyphenols amid continued administration of thioacetamide for 30 days. Based on the data obtained, it can be concluded that the natural polyphenols which belong to the classes of dihydroflavonols (dihydromyricetin) and stilbenes (resveratrol and pinosylvin) have a positive effect on liver function in the experimental model of toxic hepatosis. The studied polyphenols can be considered as potential hepatoprotective drugs used as a part of the liver diseases complex therapy.

Keywords: polyphenol, resveratrol, dihydromyricetin, pinosylvin, thioacetamide, steatosis, hepatitis, rat

Funding: the study was supported by the Ministry of Education and Science of the Russian Federation (agreement № 14.616.21.0083, unique project ID: RFMEFI61617X0083). Acknowledgement: we thank to the Center for Precision Genome Editing and Genetic Technologies for Biomedicine (Moscow) for the genetic research methods. Author contribution: Dergachova $\mathrm{DI}$ — conducting experiments on toxic hepatitis induction, histological analysis, manuscript draft preparation; Klein OI — histological studies, data acquisition and analysis; Marinichev AA - experiments on toxic hepatitis induction, blood sample collection from experimental animals, preparation of histological samples; Gessler NN - conducting experiments on toxic hepatitis induction, blood sample collection from experimental animals, data acquisition and analysis; Bogdanova ES, Smirnova MS — literature analysis, data acquisition and analysis; Isakova EP — conducting experiments on toxic hepatitis induction, literature analysis; Deryabina YI — experiment planning, literature analysis, data acquisition and analysis.

Compliance with ethical standards: the study was approved by the Ethics Committee of Bach Institute of Biochemistry RAS (protocol № 17 dated September $5,2019)$. The animals' care as well as all procedures and experimental protocols complied with the Ministry of Health of the Russian Federation requirements and to the Council Directive of November 24, 1986 (86/609/EEC).

$\triangle$ Correspondence should be addressed: Maria S. Smirnova

Moskvina, 10-226, Khimki, Moscow Region, 141401; mbarbotko@ya.ru

Received: 26.10.2019 Accepted: 17.11.2019 Published online: 27.11.2019

DOI: $10.24075 /$ brsmu.2019.075

\section{ГЕПАТОПРОТЕКТОРНОЕ ДЕЙСТВИЕ ПОЛИФЕНОЛОВ ПРИ ЭКСПЕРИМЕНТАЛЬНОЙ ТОКСИЧЕСКОЙ ПАТОЛОГИИ ПЕЧЕНИ, ВЫЗВАННОЙ ТИОАЦЕТАМИДОМ}

Д. И. Дергачева', О. И. Кляйн1, А. А. Мариничев ${ }^{1,2}$, Н. Н. Гесслер 1 Е. С. Богданова ${ }^{3}$, М. С. Смирнова ${ }^{3 凶}$ Е. П. Исакова', Ю. И. Дерябина

${ }^{1}$ Институт биохимии имени А. Н. Баха, Федеральный исследовательский центр «Фундаментальные основы биотехнологии» РАН, Москва, Россия

2 Московский химико-технологический университет имени Д. И. Менделеева, Москва, Россия

${ }^{3}$ Институт общей генетики имени Н. И. Вавилова, Москва, Россия

Неалкогольная жировая дисфункция печени сопровождает целый ряд заболеваний (диабет, ожирение, кардиоваскулярные болезни), а также может развиваться под действием лекарственных препаратов или токсических соединений. Актуальным направлением современной медицины является поиск эффективных средств профилактики и лечения жирового гепатоза. Целью работы было исследовать действие некоторых биологически активных природных полифенолов - стильбенов ресвератрола и пиносильвина, а также дигидрофлавонола дигидромирицетина — на функциональное состояние и гистологическую картину печени. В модели токсического гепатита, вызываемого введением гепатотоксиканта тиоацетамида, самцам крыс линии Wistar внутрижелудочно ежедневно вводили зондом эффективные дозы полифенолов на фоне добавления тиоацетамида к питьевой воде в концентрации 0,05\%. Все исследованные полифенолы способствовали стабилизации веса крыс и двухкратному достоверному ( $>$ < 0,05) снижению уровня прямого билирубина в сыворотке крови животных, получавших тиоацетамид. Гистологическое исследование печени подтвердило замедление воспалительных процессов и уменьшение кровоизлияний у животных, получавших полифенолы на фоне продолжающегося введения тиоацетамида в течение 30 дней. На основании полученных данных можно сделать выводы, что природные полисенолы класса дигидрофлавонолов (дигидромирицетин) и стильбенов (ресвератрол и пиносильвин) оказывают положительное воздействие на функции печени в модели экспериментального токсического гепатоза; исследованные полифенолы можно рассматривать в качестве потенциальных гепатопротекторов в составе комплексной терапии при заболеваниях печени.

Ключевые слова: полифенол, ресвератрол, дигидромирицетин, пиносильвин, тиоацетамид, стеатоз, гепатит, крыса

Финансирование: работа выполнена при поддержке Министерства образования и науки РФ (соглашение № 14.616.21.0083, уникальный идентификатор проекта RFMEFI61617X0083)

Благодарности: авторы признательны Центру высокоточного редактирования и генетических технологий для биомедицины (Москва) за помощь в методах исследования.

Информация о вкладе авторов: Д. И. Дергачева - проведение экспериментов по индукции токсического гепатита, проведение и анализ гистологических исследований, подготовка черновика рукописи; О. И. Кляйн - подготовка и проведение гистологических исследований, сбор, анализ и интерпретация данных; А. А. Мариничев - проведение экспериментов по индукции токсического гепатита, отбор проб крови экспериментальных животных, приготовление гистологических препаратов; Н. Н. Гесслер - проведение экспериментов по индукции токсического гепатита, отбор проб крови экспериментальных животных, сбор, анализ и интерпретация данных; Е. С. Богданова и М. С. Смирнова - анализ литературы, сбор, анализ и интерпретация данных; Е. П. Исакова - проведение экспериментов по индукции токсического гепатита, анализ литературы; Ю. И. Дерябина планирование исследования, анализ литературы, сбор, анализ и интерпретация данных.

Соблюдение этических стандартов: исследование одобрено этическим комитетом Института биохимии имени А. Н. Баха (протокол № 17 от 5 сентября 2019 г.). Содержание животных, все проведенные процедуры и экспериментальные протоколы соответствовали требованиям Минздрава России, а также директиве Совета Европейских сообществ от 24 ноября 1986 года (86/609/EЕC).

$\bowtie$ Для корреспонденции: Мария Сергеевна Смирнова

ул. Москвина, 10-226, г. Химки, Московская обл., 141401; mbarbotko@уa.ru

Статья получена: 26.10.2019 Статья принята к печати: 17.11.2019 Опубликована онлайн: 27.11.2019

DOI: 10.24075 /vrgmu.2019.075 
Liver diseases include a wide range of pathologies, from fatty hepatosis (steatosis) and hepatitis to liver cirrhosis and hepatocellular carcinoma. These disorders are common all over the world and have high social significance [1]. Hepatic failure, especially its severe form caused by liver cirrhosis, is on the $12^{\text {th }}$ place among the causes of deaths in the world [2]. The cirrhosis not only leads to impaired liver function, but also causes the hepatic encephalopathy syndrome which is associated with cognitive function and psychomotor impairment. Hepatic syndrome can be a cause of disability [3]. Over the past 10 years, non-alcoholic fatty liver dysfunction has become the main type of the liver chronic lesions. It has been revealed in more than $30 \%$ of population [4]. Fatty hepatosis is statistically associated with diabetes mellitus, cardiovascular diseases and obesity. The occurrence of fatty hepatosis is provoked by the use of drugs and exposure to toxicants. Association of steatosis with other chronic diseases, such as sleep apnea, colorectal cancer, osteoporosis, psoriasis and endocrine disorders, has been revealed [5]. Non-alcoholic fatty liver disease is a non-specific response of hepatocytes to toxic effects. It is characterized by an abnormal fat accumulation in the liver. In patients with severe fatty liver dystrophy, steatomas and proliferation of connective tissue can be observed, which lead to functional disorders of the liver and associated systemic pathologies.

Multiple signaling and metabolic pathways involved in the regulation of liver function make it possible to select therapeutic targets [6]. Various agents are used as hepatoprotective compounds as part of complex therapy: antibiotics (neomycin, paromycin, metronidazole, vancomycin, rifaximin) [7] and poorly digested disaccharides (lactulose, lactitol) [8], natural amino acids and nitrogen metabolites (ornithine aspartate, branched chain amino acids) [9], modulators of gut microbiota (probiotics, synbiotics) [10], bile acids derivatives and thyroid hormone receptors $\beta$-agonists [11]. However, the currently existing means for the liver pathologies of varying severity and etiology prevention and treatment include mainly symptomatic drugs of a rather wide range of effects. A significant amount of these drugs is either not recommended for prolonged use or is not approved in a number of countries. Essential phospholipids (EPL), ursodeoxycholic acid (UDCA), milk thistle extract based drugs, ademethionine can be distinguished as long-term use hepatoprotective drugs with high proven efficacy and safety [12].

Natural polyphenols are now widely used as antioxidant pharmacological substances that have a general antiinflammatory, neuro- and cardioprotective effect simulate autophagy and protect mitochondria from pathological events inducing the cell survival signaling pathways [13]. The success of the use of polyphenols for the treatment of complex etiology diseases (neurodegenerative disorders of various origins, autoimmune, allergic, oncological and prion diseases) is associated with the direct effect on the cells of the body defense systems and the main tissues cells apoptosis induction [14]. Plant polyphenols affect oxidative stress, lipid metabolism, insulin resistance and inflammation, which are the most important pathological processes in the etiology of the liver diseases [1]. The positive effect of some polyphenols on the liver functional state in a model of toxic hepatitis induced by various hepatotoxicants was demonstrated. This, quercetin natural flavonoid protected the liver from carbon tetrachlorideinduced dysfunction $\left(\mathrm{CCl}_{4}\right)$. The authors associated its action mechanism with antioxidant effect, as well as with the suppression of a number of reactions with $\mathrm{NF}-\mathrm{\kappa B}$, which led to a decrease in the level of inflammatory liver cytokines [15]. Another flavonoid, puerarin, also significantly attenuated the effects of $\mathrm{CCl}_{4}$ - induced hepatotoxicity by reducing the production of reactive oxygen species (ROS), activating the antioxidant enzyme system, and regulating the expression of genes responsible for liver lipid biosynthesis and metabolism [16]. The isolated from skullcap (Scutellaria radix Georgi) baikalin flavonoid was effective in protecting the liver from acetaminophen-induced toxic damage due to suppression of the extracellular signal-regulated kinase pathway signaling [17].

Administration of thioacetamide (TAA) leads to the liver fibrosis and cirrhosis induction in rats and mice. In a number of studies, 2 weeks after the start of TAA administration a significant increase in the activity of hepatic aminotransferases (alanine aminotransferase (ALT) and aspartate aminotransferase (AST)) was observed, indicating the development of a pathological process. By the end of the $4^{\text {th }}$ week, the activity of AST and ALT was back to normal, while the level of collagen in the liver tissue increased [18]. Oxidative stress is considered the main factor of TAA-induced liver fibrous degeneration caused by the thioacetamide-S-oxide toxic metabolite formed during the transformation of TAA by cytochrome P450 family enzymes (CYP1A2, CYP2C6, CYP2E1, CYP3A2) and microsomal FAD-containing monooxygenases [19, 20]. According to the published data, resveratrol significantly reduced the TAAinduced liver damage. The mechanism of its action is due to a decrease in the intensity of oxidative stress, the suppression of the NF-kB- dependent cascade and apoptosis [21].

Our work was aimed to investigate the potential hepatoprotective effect of stilbene-type polyphenols (resveratrol (RSV) and pinosilvin (PS)) and dihydromyricetin (DHM) dihydroflavonol on the functional state and histological picture of the liver in a rat model of TAA-induced toxic hepatitis.

\section{METHODS}

Experiments were conducted on the male white rats of the Wistar line (initial weight of the rats was 190-230 g) obtained from Stolbovaya breeding nursery (Moscow Region). The animals' care in the breeding nursery complied with the GLP requirements. During the experiment the animals were kept in vivarium with natural light (day 12 hours, night 12 hours), the nutritionally balanced laboratory animal diet was used in accordance with GOST Standard P502580092. The study was carried in accordance with the Guidelines for Preclinical Trials of Medicinal Products (2 parts, editor Mironov AN (latest version)) and corresponding regulatory documents.

To induce toxic liver damage and the development of liver pathology, 0.05\% TAA aqueous solution was administered to animals with food daily, which demonstrated a high efficiency in developing a liver pathology model [18, 20]. The TAA administration led to liver fibrosis and cirrhosis induction in rats and mice.

The rats were divided into groups of 10 animals:

1 - group of intact animals which were kept on a normal diet;

2 - group of control animals which received $0.05 \%$ TAA in drinking water;

3 - treatment group which received 0.05\% TAA in drinking water together with RSV ( $15 \mathrm{mg} / \mathrm{kg}$ orally);

4 - treatment group which received $0.05 \%$ TAA in drinking water together with DHM (10 mg/kg orally);

5 - treatment group which received $0.05 \%$ TAA in drinking water together with PS ( $5 \mathrm{~g} / \mathrm{kg}$ orally).

TAA was administered to animals during 30 days. Examination of animals was carried out daily, weighing was carried out every 3 days. Polyphenols were isolated and purified from plant raw materials (coniferous biomaterials available in 
Russian Federation). Polyphenols were administered as a solution in an aqueous $2 \%$ starch gel intragastically by gavage daily after feeding at a dose of not more than $0.4 \mathrm{ml}$ for each animal. Animals' blood and liver samples for biochemical and histological studies were collected on the $10^{\text {th }}, 20^{\text {th }}$, and $30^{\text {th }}$ days of the experiment. Liver tissue and blood samples were collected immediately after autopsy. The direct bilirubin and enzyme activity (AST and ALT aminotransferases) in the blood serum samples were assayed using the AU 480 Chemistry Analyzer (Beckman Coulter; USA). Blood chemistry tests for the laboratory animals were carried out in the Bio Chance Independent Veterinary Laboratory (participant of the Federal System of External Quality Assessment of Clinical Laboratory Testing, ID 10705) using the AU Chemistry Analyzer 480 (Beckman Coulter; USA), BA 400 analyzer (BioSystems; Spain) and Abacus Vet 4 analyzer (Diatron; Austria). The fatty liver index was determined as the ratio of the weight of organ to body weight (\%). For histological studies, liver fragments were taken from the lower part of the right lobe. Histological preparations (thin sections) were obtained by making paraffin microsections according to the method described in [22]. Sample preparation included the following stages:

1. Preparation of organs for placement into the $4 \%$ paraformaldehyde (PFA) solution in phosphate-buffered saline (PBS). The collected during autopsy rat organs were kept in the plates with 4\% PFA for 30 minutes. Every 30 min, a 4\% PFA was changed thrice, after which the organs were left for 24 hours at a temperature of $+4^{\circ} \mathrm{C}$.

2. Preparation of organs for placement in the sealing media was carried out according to the following procedure: a) washing 3 times with PBS for 30 min at $+4{ }^{\circ} \mathrm{C}$; b) incubation in $70 \%$ ethanol, 3 turns 30 min each; c) incubation in $80 \%$ ethanol for 40 minutes; d) incubation in the $82 \%$ ethanolbutanol mixture (3:1) for 40 minutes; e) incubation in the $96 \%$ ethanol-butanol mixture (1:1) for 50 minutes; f) incubation in the 100\% ethanol (absolute) - butanol mixture (1:3) for 50 minutes; g) incubation in butanol I for 1 hour; h) incubation in butanol II for 1 hour.

3. Organs embedding in paraffin wax. Paraffin wax heated to $+60{ }^{\circ} \mathrm{C}$ was poured in the prepared and heated foil mold, after that the sample was placed in paraffin wax. Paraffin wax blocks had been dried for 10-12 hours.

4. Sections preparation for staining. Cooled paraffin blocks were fixed on a wooden block with melted paraffin. Sections (slices) were obtained using the MC-2 sliding microtome (Tochmedpribor; Russia). Then the slices were mounted on the glass slides and placed in a dryer for $30 \mathrm{~min}$ at a temperature of $+40^{\circ} \mathrm{C}$.
5. Staining of sections. Before staining, paraffin wax was removed from slices using toluene or xylene. Sections were stained using the hematoxylin-eosin staining system. After staining, Immuno Mount with DABCO ${ }^{\mathrm{TM}}$ (Genetex; Canada) was applied to sections and a glass cover was placed on top.

Statistical analysis was performed using STATISTICA 6.0 software for personal computer (Dell; USA). Data were presented as arithmetic mean and standard error of the mean $(\mathrm{M} \pm m)$. Student t-test was used for evaluation of the differences between groups of animals. The differences were considered significant when $p<0.05$.

\section{RESULTS}

The animals' weight dynamics assessment demonstrated that the body weight of intact animals increased throughout the entire period of the experiment (Fig. 1, curve 1). Against the background of the TAA introduction, regardless of the administration of polyphenols, the weight of the animals decreased significantly during the first week of the experiment. The polyphenols administration provided a positive trend in increasing the animals' weight compared with the control group, starting from the third week, which could indicate a positive effect of polyphenols on the liver function. By the end of the experiment, the liver index (the ratio of organ mass to animal body weight) increased from $3.65 \pm 0.2$ in intact animals to $5.1 \pm 0.3$ in treated with TAA animals of the control group. In the groups treated with polyphenols together with TAA, the liver index was $4.5 \pm 0.19,4.6 \pm 0.23$ and $4.4 \pm 0.16$ for animals treated with RSV, DHM and PS respectively. A decrease in the liver index in animals treated with polyphenols indicated a decrease in pathological changes caused by the TAA administration.

Analysis of the biochemical blood parameters dynamics of laboratory animals treated with TAA demonstrated that the level of bilirubin in the blood increased by almost 10 times, while the administration of polyphenols decreased that indicator by 2-4 times (Table 1). It should be noted that the effect of lowering serum bilirubin level was observed throughout the entire period of the polyphenols administration. The total protein and glucose level decreased slightly in all treated with TAA groups, regardless of the administration of polyphenols (no significant differences, data not shown).

AST activity significantly increased $(p<0.05)$ in the blood serum of animals in all treated with TAA groups compared to control (Fig. 2A). An almost twofold AST increase in animals of the control group by the $20^{\text {th }}$ day and then a slight decrease

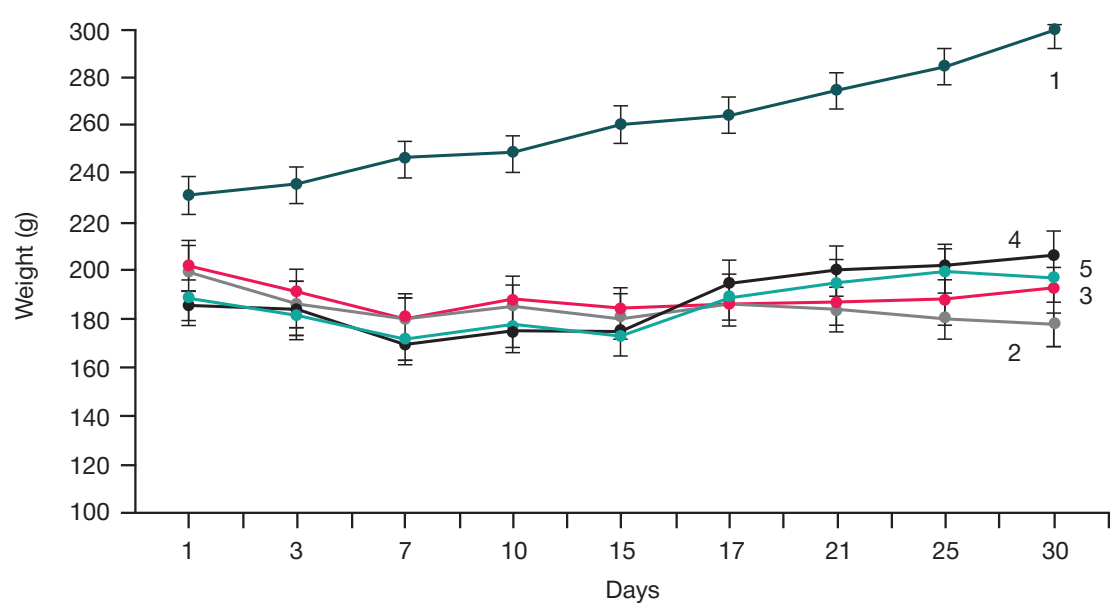

Fig. 1. Dynamics of animals' weight changes during the experiment: 1 - intact animals group; 2 - control group treated with TAA; $3-5-$ groups of animals treated with TAA together with polyphenols (RSV, DHM and PS respectively) 
Table 1. Bilirubin level change in the blood serum of rats during the experiment

\begin{tabular}{|c|c|c|c|c|c|}
\hline \multirow{2}{*}{ Period } & \multicolumn{5}{|c|}{ Direct bilirubin, $\mu \mathrm{mol} / \mathrm{l}$} \\
\hline & Intact & Control & RSV & DHM & PS \\
\hline 10 days & $0.4 \pm 0.1$ & $4.9 \pm 0.5^{*}$ & $1.1 \pm 0.2^{*}{ }^{* *}$ & $1.5 \pm 0.6^{*} .{ }^{* \star}$ & $1.2 \pm 0.6^{*} .^{* *}$ \\
\hline 20 days & $0.4 \pm 0.2$ & $4.4 \pm 0.5^{*}$ & $2.0 \pm 0.8^{*}{ }^{* *}$ & $1.3 \pm 0.5^{\star *}{ }^{* \star}$ & $2.5 \pm 0.2^{\star *}{ }^{* \star}$ \\
\hline 30 days & $0.45 \pm 0.2$ & $4.2 \pm 1.1^{*}$ & $1.1 \pm 0.1^{*}$.** & $2.4 \pm 0.6^{*}$.** & $1.5 \pm 0.7^{*}$.** \\
\hline
\end{tabular}

Note: ${ }^{\star}-p<0.05$ in relation to corresponding indicators of intact animals group; ${ }^{\star}-p<0.05$ in relation to corresponding indicators of control group.

by the $30^{\text {th }}$ day of the experiment is characteristic of this hepatotoxicity model, it is in line with the data of other authors $[18,21]$. In rats receiving polyphenols, AST was lower. By the end of the experiment, in the groups receiving resveratrol and pinosylvin, a significant decrease in this indicator was observed compared to the control group (Fig. 2A).

ALT activity in the control group receiving TAA significantly increased $(p<0.05)$ by $40 \%$ only after the 20th day of the experiment (Fig. 2B). An increase in ALT activity in the middle of the experiment was also noted in animals which received RSV together with TAA (about 30\%), as well as slight increase $(20 \%)$ in animals which received PS by the 30th day of the experiment. In the group treated with DHM, ALT values did not differ from those in intact animals throughout the observation period. By the end of the experiment, ALT values were back to normal in animals of the RSV-treated group (Fig. 2B).

At the next stage, histological sections of the liver of all the studied treatment groups of animals were analyzed. Hepatocytes of intact animals were characterized by normal cytomorphology with well-defined nuclei and moderate tissue polymorphism (Fig. 3A). TAA hepatotoxicant intoxication led to diapedetic hemorrhage (Fig. 3B) and small-droplet (microvesicular) steatosis. The obtained histological picture corresponded to the known symptoms of liver pathology arising due to the action of xenobiotics (TAA and $\mathrm{CCl}_{4}$ ) [23]. Administration of polyphenols (Fig. 3D-F) prevented significant degradation of liver tissue: hepatocytes structure violation, the development of hematomas and inflammation foci containing small cell formations (Fig. 3D-F).

\section{DISCUSSION}

The positive effect of a number of natural polyphenols on hepatotoxicant-induced liver pathologies is well known. The quercetin flavonoid exhibited a protective effect on the CCl4-induced toxic hepatitis in mice [15]. Eisenia bicyclis (Kjellman) Setchell brown algae polyphenol dieckol protected the liver of mice from $\mathrm{CCl}_{4}$-induced destruction through regulation of genes responsible for the expression of apoptotic proteins Bax and Bcl-xl [24]. In the other work, isorhamnetin 3-O-galactoside polyphenol isolated from Artemisia capillaris Thunberg also had a positive effect on $\mathrm{CCl}_{4}$-induced liver pathology by decreasing the level of phosphorylated c-JNK, extracellular signal-regulated kinase (ERK) and p38 MAPK [25]. The baikalin flavonoid had a significant protective effect in mice with acetaminophen-induced hepatitis [17]. In the model of TAA-induced toxic liver damage used in our work, the protective effect of polyphenols was studied only on the example of the RSV stilbene polyphenol. In the recent work [21], RSV-induced inflammation and oxidative stress inhibition in rat liver tissues due to reduction of the expression level of $\mathrm{NF}-\mathrm{kB}$ and CYP2E1 as well as necrotic hepatocytes apoptosis

A
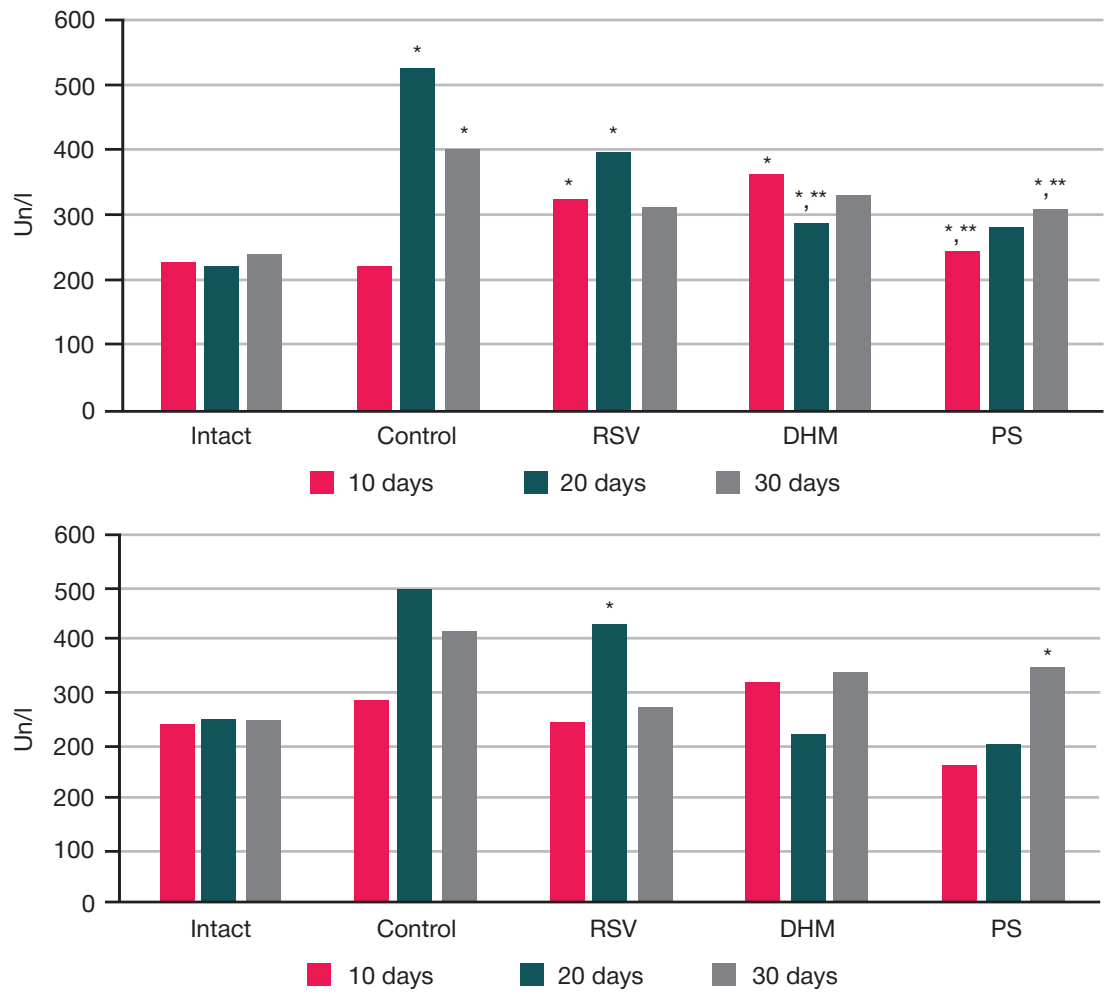

Fig. 2. AST (A) and ALT (B) change in the blood serum of rats during the experiment. * $-p<0.05$ in relation to corresponding indicators of intact animals group; ${ }^{* *}-p<0.05$ in relation to corresponding indicators of control group 

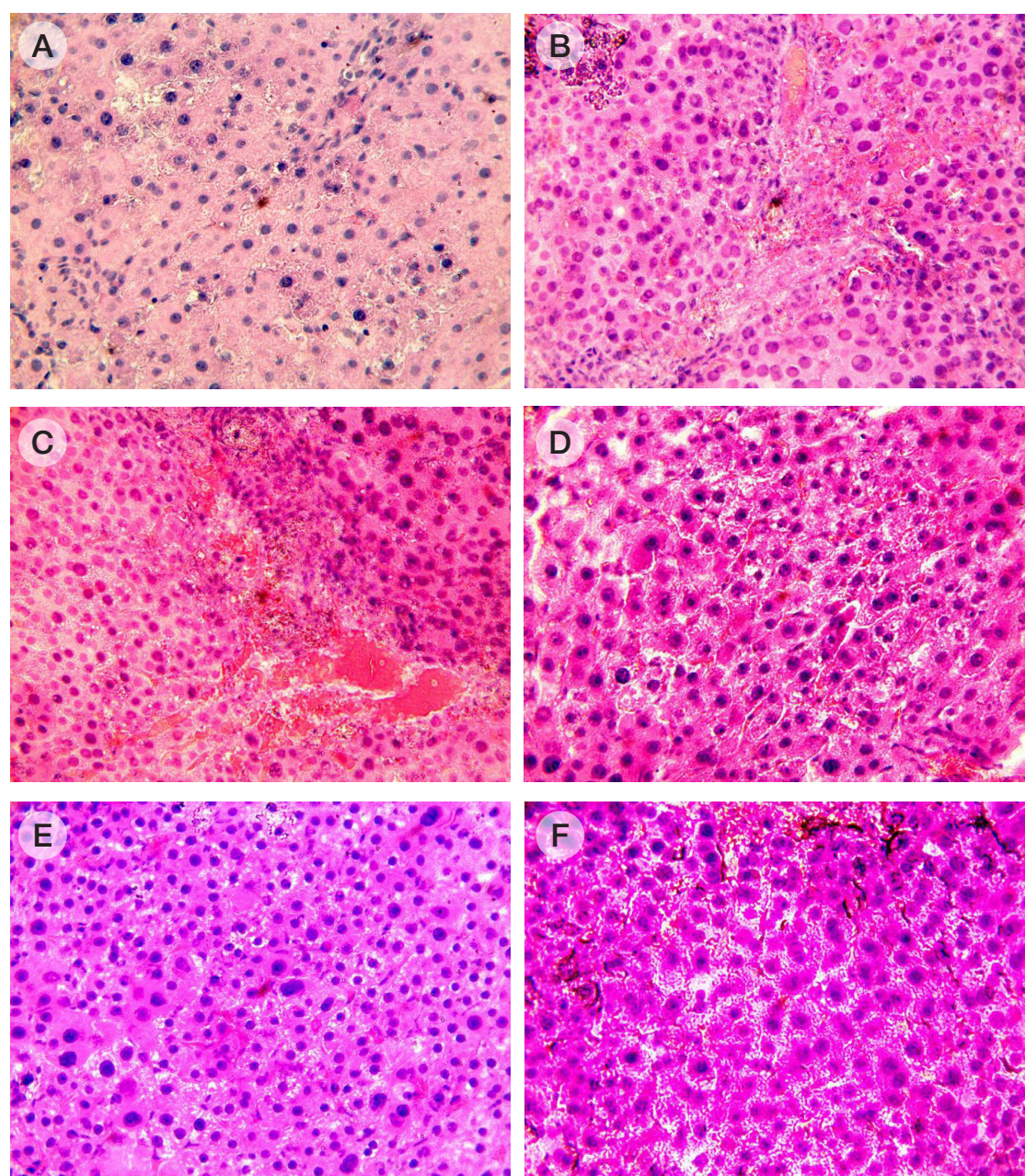

Fig. 3. Micrographs of treatment groups animals' liver sections stained with hematoxylin-eosin. A. Intact animals group (1). B, C. Control group (2). D. Treatment group (3). E. Treatment group (4). F. Treatment group (5). Magnification $\times 400$

increase was demonstrated. In addition, stabilization of blood biochemical parameters (ALT and AST) was shown as well as normalization of tissue architecture of the liver in laboratory animals receiving RSV (10 mg/kg per animal). Given these data, we can assume that in our studies there is a similar mechanism of RSV action, based on its powerful antioxidant effect. There are no literature data on the effects of DHM and PS in the model of toxic hepatitis induction in laboratory animals. There is only evidence of a pro-apoptotic effect of DHM on HepG2 cells of hepatocellular carcinoma [26]. Given the high biological activity of these polyphenols in various disorder models, it can be assumed that the protective effect of DHM and PS studied by us in rats with TAA-induced hepatopathology can also be associated with powerful antioxidant potential.

Some authors [27] demonstrated, that dioscin (saponin isolated from Dioscorea nipponica Makino), like the studied by us polyphenols, decreased the TAA hepatotoxicity, increasing the level of glutathione in the liver cells and the activity of the glutathione peroxidase and superoxid dismutase antioxidant enzymes, decreasing the content of malondialdehyde. Treatment of animals by dioscin increased the expression of FXR and p-AMPKa, as well as Nrf2, HO-1, NQO-1 and GCLM. On the contrary, the level of proinflammatory factors NF- $\kappa B$ (p65), ICAM 1, HMGB1, COX-2, TNF $\alpha$, IL1 $\beta$ and IL6 in the liver cells decreased due to dioscin administration, which, according to the authors, was evidence of the ability of said natural compound to suppress TAA hepatotoxicity due to the FXR/AMPK signaling pathway weakening in hepatocytes.

\section{CONCLUSION}

The study has shown that the natural polyphenols which belong to the class of dihydroflavonols (DHM) and stilbenes (RSV and PS) have a positive effect on liver function in the experimental model of toxic hepatosis and can be considered as potential hepatoprotectors.

\section{References}

1. Li S, Tan HY, Wang N, Cheung F, Hong M, Feng Y. The potential and action mechanism of polyphenols in the treatment of liver diseases. Oxid Med Cell Longev. 2018; 8394818. DOI: 10.1155/2018/8394818.

2. Raff E, Singal AK. Optimal management of alcoholic hepatitis. Minerva Gastroenterol Dietol. 2014; 60 (1): 25-38.
3. Riggio O, Ridola L, Pasquale C. World J Gastrointest Pharmacol Ther Hepatic encephalopathy therapy: An overview. 2010; 1 (2): 54-63.

4. Neuschwander-Tetri BA. Non-alcoholic fatty liver disease. BMC Med. 2017; 15 (1): 45.

5. Popov VB, Lim JK. Treatment of nonalcoholic fatty liver disease: 
The role of medical, surgical, and endoscopic weight loss. J Clin Transl Hepatol. 2015; 3 (3): 230-38.

6. Hong M, Li S, Tan H, Wang N, Tsao SW, Feng Y. Current status of herbal medicines in chronic liver disease therapy: the biological effects, molecular targets and future prospects. Int J Mol Sci. 2015; 16 (12): 28705-45.

7. Festi D, Vestito A, Mazzella G, Roda E, Colecchia A. Management of hepatic encephalopathy: focus on antibiotic therapy. Digestion. 2006; 73 (Suppl. 1): 94-101.

8. Malaguarnera M, Gargante MP, Malaguarnera G, Salmeri M, Mastrojeni S, Rampello L, et al. Bifidobacterium combined with fructo-oligosaccharide versus lactulose in the treatment of patients with hepatic encephalopathy. Eur J Gastroenterol Hepatol. 2010; 22 (2): 199-206.

9. Efrati C, Masini A, Merli M, Valeriano V, Riggio O. Effect of sodium benzoate on blood ammonia response to oral glutamine challenge in cirrhotic patients: a note of caution. Am J Gastroenterol. 2000; 95 (12): 3574-78.

10. Plauth M, Cabre E, Riggio O, Assis-Camilo M, Pirlich M, Kondrup J, et al. ESPEN guidelines on enteral nutrition: liver disease. Clin Nutr. 2006; 25 (2): 285-94.

11. Wong VW, Singal AK. Emerging medical therapies for nonalcoholic fatty liver disease and for alcoholic hepatitis. Transl Gastroenterol Hepatol. 2019; (4): 53.

12. Minushkin ON, Maslovsky LV, Bukshuk AA. The use of hepatic protectors in clinical practice. Zh Nevrol Psikhiatr Im SS Korsakova. 2012; 10 (2): 67-72.

13. Teplova W, Isakova EP, Klein OI, Dergacheva DI, Gessler NN, Deryabina YI. Natural Polyphenols: Biological Activity, Pharmacological Potential, Means of Metabolic Engineering (Review). Applied Biochemistry and Microbiology. 2018; 54 (3): 221-37.

14. Quideau S, Deffieux D, Douat-Casassus C, Pouysegu L. Plant polyphenols: chemical properties, biological activities, and synthesis. Angewandte Chemie Intern Edition. 2011; 50 (3): 586-621.

15. Ma JQ, Li Z, Xie WR, Liu CM, Liu SS. Quercetin protects mouse liver against $\mathrm{CCl} 4$-induced inflammation by the TLR2/4 and MAPK/NF-kB pathway. Intern Immunopharm. 2014; 28 (1): 531-39.

16. Ma JQ, Ding J, Zhao H, Liu CM. Puerarin attenuates carbon tetrachloride-induced liver oxidative stress and hyperlipidaemia in mouse by JNK/c-Jun/CYP7A1 pathway. Basic Clin Pharmacol Toxicol. 2014; 115 (5): 389-95.

\section{Литература}

1. Li S, Tan HY, Wang N, Cheung F, Hong M, Feng Y. The potential and action mechanism of polyphenols in the treatment of liver diseases. Oxid Med Cell Longev. 2018; 8394818. DOI: 10.1155/2018/8394818.

2. Raff E, Singal AK. Optimal management of alcoholic hepatitis. Minerva Gastroenterol Dietol. 2014; 60 (1): 25-38

3. Riggio O, Ridola L, Pasquale C. World J Gastrointest Pharmacol Ther Hepatic encephalopathy therapy: An overview. 2010; 1 (2): 54-63.

4. Neuschwander-Tetri BA. Non-alcoholic fatty liver disease. BMC Med. 2017; 15 (1): 45

5. Popov VB, Lim JK. Treatment of nonalcoholic fatty liver disease: The role of medical, surgical, and endoscopic weight loss. J Clin Transl Hepatol. 2015; 3 (3): 230-38.

6. Hong M, Li S, Tan H, Wang N, Tsao SW, Feng Y. Current status of herbal medicines in chronic liver disease therapy: the biological effects, molecular targets and future prospects. Int J Mol Sci. 2015; 16 (12): 28705-45.

7. Festi D, Vestito A, Mazzella G, Roda E, Colecchia A. Management of hepatic encephalopathy: focus on antibiotic therapy. Digestion. 2006; 73 (Suppl. 1): 94-101.

8. Malaguarnera M, Gargante MP, Malaguarnera G, Salmeri M, Mastrojeni S, Rampello L, et al. Bifidobacterium combined with fructo-oligosaccharide versus lactulose in the treatment of patients with hepatic encephalopathy. Eur J Gastroenterol Hepatol. 2010; 22 (2): 199-206
17. Liao CC, Day YJ, Lee HC, Liou JT, Chou AH, Liu FC. ERK signaling pathway plays a key role in baicalin protection against acetaminophen-induced liver injury. Am J Chinese Med. 2017; 45 (1): 105-21.

18. Wallace MC, Hamesch $\mathrm{K}$, Lunova M, Kim Y, Weiskirchen R, Strnad $\mathrm{P}$, et al. Standard operating procedures in experimental liver research: thioacetamide model in mice and rats. Laboratory Animals. 2015; 49 (S1): 21-9.

19. Xie $\mathrm{Y}$, Wang $\mathrm{G}$, Wang $\mathrm{H}$, Yao $\mathrm{X}$, Jiang $\mathrm{S}$, Kang $\mathrm{A}$, et al. Cytochrome P450 dysregulations in thioacetamide-induced liver cirrhosis in rats and the counteracting effects of hepatoprotective agents. Drug Metabolism and Disposition. 2012; 40 (4): 796-802.

20. Ingawale DK, Mandlik SK, Naik SR. Models of hepatotoxicity and the underlying cellular, biochemical and immunological mechanism(s): a critical discussion. Environ Toxicol Pharmacol. 2014; 37 (1): 118-33.

21. Seif El-Din SH, El-Lakkany NM, Salem MB, Hammam OA, Saleh S, Botros SS. Resveratrol mitigates hepatic injury in rats by regulating oxidative stress, nuclear factorkappa B, and apoptosis. J Advanc Pharmaceut Technol Res. 2016; 7 (3): 99-104.

22. Frank GA, Malkov PG, редакторы. 101 shag na puti $k$ uspekhu v gistologii. Leica Microsystems Vetzlar, Germany, 2012; 136 c. Russisn.

23. Kang MC, Kang SM, Ahn G, Kim KN, Kang N, Samarakoon KW, et al. Protective effect of a marine polyphenol, dieckol against carbon tetrachlorideinduced acute liver damage in mouse. Environ Toxicol Pharmacol. 2013; 35 (3): 517-23.

24. Kang MC, Kang SM, Ahn G, Kim KN, Kang N, Samarakoon KW, et al. Protective effect of a marine polyphenol, dieckol against carbon tetrachlorideinduced acute liver damage in mouse. Environ Toxicol Pharmacol. 2013; 35 (3): 517-23.

25. Kim DW, Cho HI, Kim KM, Kim YS. Isorhamnetin-3-O-galactoside protects against $\mathrm{CCl} 4$-induced hepatic injury in mice. Biomolecules Therapeutics. 2012; 20 (4): 406-12.

26. Huang X, Lian T, Guan X, Liu B, Hao S, Zhang J, et al, Dihydromyricetin reduces TGF- $\beta$ via P53 activation-dependent mechanism in hepatocellular carcinoma HepG2 cells. Protein Pept Lett. 2017; 24 (5): 419-24.

27. Zheng L, Yin L, Xu L, Qi Y, Li H, Xu Y, et al. Protective effect of dioscin against thioacetamide-induced acute liver injury via FXR/ AMPK signaling pathway in vivo. Biomed Pharmacother. 2018; (97): 481-8. DOI: 10.1016/j.biopha.2017.10.153.

9. Efrati C, Masini A, Merli M, Valeriano V, Riggio O. Effect of sodium benzoate on blood ammonia response to oral glutamine challenge in cirrhotic patients: a note of caution. Am J Gastroenterol. 2000; 95 (12): 3574-78.

10. Plauth M, Cabre E, Riggio O, Assis-Camilo M, Pirlich M, Kondrup J, et al. ESPEN guidelines on enteral nutrition: liver disease. Clin Nutr. 2006; 25 (2): 285-94

11. Wong VW, Singal AK. Emerging medical therapies for nonalcoholic fatty liver disease and for alcoholic hepatitis. Transl Gastroenterol Hepatol. 2019; (4): 53.

12. Минушкин О. Н., Масловский Л. В., Букшук А. А. Применение гепатопротекторов в клинической практике. Журнал неврологии и психиатрии им. С. С. Корсакова. 2012; 10 (2): 67-72.

13. Теплова В. В., Исакова Е. П., Кляйн О. И., Дергачева Д. И., Гесслер Н. Н., Дерябина Ю. И. Природные полисенолы: биологическая активность, фармакологический потенциал, пути метаболической инженерии (Обзор). Прикладная биохимия и микробиология. 2018; 54 (3): 215-35.

14. Quideau S, Deffieux D, Douat-Casassus C, Pouysegu L. Plant polyphenols: chemical properties, biological activities, and synthesis. Angewandte Chemie Intern Edition. 2011; 50 (3): 586-621.

15. Ma JQ, Li Z, Xie WR, Liu CM, Liu SS. Quercetin protects mouse liver against CCl4-induced inflammation by the TLR2/4 and MAPK/NF-KB pathway. Intern Immunopharm. 2014; 28 (1): 531-39.

16. Ma JQ, Ding J, Zhao H, Liu CM. Puerarin attenuates carbon tetrachloride-induced liver oxidative stress and hyperlipidaemia 
in mouse by JNK/c-Jun/CYP7A1 pathway. Basic Clin Pharmacol Toxicol. 2014; 115 (5): 389-95.

17. Liao CC, Day YJ, Lee HC, Liou JT, Chou AH, Liu FC. ERK signaling pathway plays a key role in baicalin protection against acetaminophen-induced liver injury. Am J Chinese Med. 2017; 45 (1): 105-21.

18. Wallace MC, Hamesch $\mathrm{K}$, Lunova M, Kim Y, Weiskirchen R, Strnad $\mathrm{P}$, et al. Standard operating procedures in experimental liver research: thioacetamide model in mice and rats. Laboratory Animals. 2015; 49 (S1): 21-9.

19. Xie $Y$, Wang $G$, Wang $H$, Yao $X$, Jiang $S$, Kang $A$, et al. Cytochrome P450 dysregulations in thioacetamide-induced liver cirrhosis in rats and the counteracting effects of hepatoprotective agents. Drug Metabolism and Disposition. 2012; 40 (4): 796-802.

20. Ingawale DK, Mandlik SK, Naik SR. Models of hepatotoxicity and the underlying cellular, biochemical and immunological mechanism(s): a critical discussion. Environ Toxicol Pharmacol. 2014; 37 (1): 118-33.

21. Seif El-Din SH, El-Lakkany NM, Salem MB, Hammam OA, Saleh S, Botros SS. Resveratrol mitigates hepatic injury in rats by regulating oxidative stress, nuclear factorkappa B, and apoptosis. J Advanc
Pharmaceut Technol Res. 2016; 7 (3): 99-104.

22. Франк Г. А., Мальков П. Г., редакторы. 101 шаг на пути к успеху в гистологии. Leica Microsystems Vetzlar, Germany, 2012; 136 c.

23. Манских В. Н. Патоморфология лабораторной мыши. М.: BAKO, 2018; 224 c.

24. Kang MC, Kang SM, Ahn G, Kim KN, Kang N, Samarakoon KW, et al. Protective effect of a marine polyphenol, dieckol against carbon tetrachlorideinduced acute liver damage in mouse. Environ Toxicol Pharmacol. 2013; 35 (3): 517-23.

25. Kim DW, Cho HI, Kim KM, Kim YS. Isorhamnetin-3-O-galactoside protects against $\mathrm{CCl} 4$-induced hepatic injury in mice. Biomolecules Therapeutics. 2012; 20 (4): 406-12.

26. Huang X, Lian T, Guan X, Liu B, Hao S, Zhang J, et al. Dihydromyricetin reduces TGF- $\beta$ via P53 activation-dependent mechanism in hepatocellular carcinoma HepG2 cells. Protein Pept Lett. 2017; 24 (5): 419-24.

27. Zheng L, Yin L, Xu L, Qi Y, Li H, Xu Y, et al. Protective effect of dioscin against thioacetamide-induced acute liver injury via FXR/ AMPK signaling pathway in vivo. Biomed Pharmacother. 2018; (97): 481-8. DOI: 10.1016/j.biopha.2017.10.153. 